\title{
Literature Review on Country-Specific Advantage
}

\author{
H. R. Zhang \\ School of Business Administration, South China University of Technology, Guangzhou, China \\ Email: emma_zhr@163.com
}

Received 25 January 2016; accepted 30 March 2016; published 5 April 2016

Copyright (C) 2016 by author and Scientific Research Publishing Inc.

This work is licensed under the Creative Commons Attribution International License (CC BY).

http://creativecommons.org/licenses/by/4.0/

(c) (i) Open Access

\begin{abstract}
During the constant research of internationalization, firms have been focused on as it is the main body that implements strategies. However, the role of a country in the process of internationalization has been ignored for a long time. Where does country-specific advantage come from? What's the relationship between country-specific advantage and firm-specific advantage? These questions haven't been understood clearly yet. Home country provides necessary infrastructure, service conditions, resources and institutions guarantee, which is the origin of firm's core competition advantages; while host country's characteristic will influence the way and path of internalization. It is of great significance to understand how to transform country-specific advantages into firm- specific advantages in the process of internationalization of multinational firms.
\end{abstract}

\section{Keywords}

Country-Specific Advantages (CSAs), Firm-Specific Advantages (FSAs), Internationalization, Multinational Firms

\section{Introduction}

The international competitive ability of enterprise consists of country-specific advantages and firm-specific advantages that both are indispensable for a successful international enterprise. Where do CSAs come from? What's the relationship between CSAs and FSAs? There is no right answer for these questions and researchers are puzzled by the mechanism of how to utilize a country's specific resources and location advantages as well as how to turn them into firm-specific advantage. Although early in the last century, some scholars [1] proposed the definition of "country-specific advantages", Rugman thought it mainly came from the country's natural resources endowments, labor resources and related cultural factors, including the quality and quantity of the main production factors, but this concept has not been systematically studied and developed. Pei thought that the home country was the cornerstone of a country's foreign investment enterprises, which provided the basic con- 
ditions for national economy. Different conditions of home country created their own trade advantages, scale advantages, location advantages, organizational advantages and other specific advantages, which formed diversified business advantages for domestic enterprises to participate in overseas investment [2]. Broadly speaking, CSAs are the advantages of a variety of country-specific resource allocation or unsynchronized uneven all over the country and forms a national comparative advantage. Country-specific advantages are all kinds of proprietary resources that a country has, and can be freely available to any business; it is a system that all the firms can share the advantages [2]-[5]. This is a kind of comparative advantage that formatted by the uneven distribution of resources all over the country, and it plays an important role in the accumulation of corporate resources [6] [7].

Existing research on CSAs is mainly concentrated on the following aspects. First, CSAs are the driving source and cornerstone of a country's FDI [8]. Zhang indicates that the CSAs of FDI is an important driving force for China, Chinese investment types in developed countries are mainly market-seeking (differentiated products), strategic asset-seeking [9]; the investment types in developing countries are mainly natural resources seeking and market seeking (standardized products) [8]. Secondly, CSAs have an influence on FDI location choice [10] [11]. Xiao indicates that different CSAs lead to the difference in location choice preferences of multinational foreign investment. The change of the economic development mode has led to the change of strategy motivation at the national level, thus affecting the location choice in a particular host country. Thirdly, CSAs affect equity options. Krishna finds that the level of South Korean multinational' three FSAs-technology-intensive, product differentiation and funding density-influence equity of subsidiary depends on the situation that subsidiary is located in relatively less developed countries or more developed countries than home country [12]. Ability to obtain equity obviously relates to their talent of specific countries, especially the origin country (origin) [13]. When enterprises from more developed try to invest in less developed locations, they tend to choose high equity model, while they prefer low equity entry mode when they enter developed countries [12]. Fourthly, CSAs affect international cooperation [14]. International companies with competitive advantages are able to get more value, technology, or other assets, which are costly and difficult to obtain in the overseas market. It is persuasive to explain internalization of enterprise by taking advantage of the concept of FSAs. While FSAs of home country are in favor of primitive accumulation of enterprises' advantages, FSAs of host country are able to attract a large number of enterprises to enter, which further contribute to the formulation of FSAs.

\section{Theory Developing of Country-Specific Advantage}

The earliest studies on country-specific advantages can be traced back to Adam Smith's “absolute advantage” in the 18th century, which based on international division labor, David Ricardo's “comparative advantage” in 19th century and Heckscher-Ohlin's “resource endowment theory” in the early 20th century and so on. These three theories define “comparative advantage” as the difference between two countries' elements from national level, both the advantages of labor productivity and labor costs as well as the advantages resulted from the absolute difference of resource endowments. This kind of comparative advantage is the reason of international trade, or we can say that is the foundation of the advantageous position in the international commodity exchange for the enterprises. Early theories about country-specific advantages are all carried out on a comparative basis. Such as monopolistic advantage theory [15] contains the conditions for choosing a right location in foreign direct investment, and it propose that enterprise had better choose a host country where company can play the comparative advantages. Wells [16] combined enterprises’ technology with host countries' production, and he indicates that developing countries' enterprise technology is more accustomed to certain host country which creates comparative advantage for them in such host countries. Marginal industry expansion theory put forward that the industrial comparative advantage and the locative advantage of host country should be combined; Small-scale technology theory indicates that it is meaningful to combine technical owned by enterprises with those in the host country.

Rugman is the first one that proposes the concept of “country-specific advantages”, he thinks it comes mainly from the country's natural resources endowments, labor resources and related cultural factors, including the main factors of production quality, quantity and price, but the concept has not been systematically studied and developed [1]. During the same period, other scholars proposes similar ideas, the main representatives are Porter and Dunning. When Porter searches for the source of the differences of industrial competitiveness, he clearly proposes that economic environment of the home country affect industrial competitiveness directly [17]. Pub- 
lished in 1990, “Competitive Advantage of Nations" [18] proposes diamond model of competitive advantage which provides important directions for later scholars to study country-specific advantages. He thinks that companies' international competitive advantage depends on whether the country can create and sustain advantages in specific areas, which is what we called country-specific advantage. This advantage contains four elements: the factors of production, demand elements, the relevant and ancillary industries and business strategy, structure and competition in the industry. If a country is stronger than other countries in these four factors in a particular field or industry, then it will bring out country-specific advantages for the enterprises [19]. Rugman and D'Cruz introduce the "Double Diamond model (generalized double diamond)", which adds the international competitiveness of the national situation [20]. But due to a structural limitation of Double Diamond model limitation, it didn't fit all [21]. Moon et al. extends this model to the DDD (dual double diamond), including domestic and international diamond model, which adopt Porter's Diamond model both in the domestic context and international context [22] [23]. In order to explain the dynamic role of human factors in international competitiveness, the "NF (nine-factor)" model [24] [25] is introduced. Although Porter sort out a logical chain of macroscopic force national competition for industry competitive advantage and with it replenished and expanded, while it is difficult to explain the competitive advantage of enterprises, especially competitive advantage across industries in a country.

The OLI paradigm proposed by Dunning, also raises the proposition that the level of economic development of the home country has a relationship with a country's foreign direct investment [13]. The enterprise ownership advantages, location advantages and internalization advantages are able to explain the behavior of enterprises' foreign direct investment. While ownership advantages and internalization advantages are the advantage in the enterprise level, location advantages refer to location factors in the host country. Dunning also proposes corporate ownership from the view of national differences, which reflects the "home country's resources and assets." The difference in non-transferable resources and assets will lead to corporate ownership advantages. But OLI framework didn't answer the question "In what extent corporate ownership advantages are home-based specific advantages" [26]? The early ideas about country-specific advantage are only a part of location advantages, and there is no specific research about the relationship between location advantage and firm-specific advantages. Mean while the role that location advantages played in a country's foreign direct investment is remain to be explored.

\section{The Source of Country-Specific Advantage}

Country-specific advantage comes mainly from two aspects: resource endowment and institutional factors. Home countries' specific resources, environment, institution and other factors are important driving forces for enterprises to form an initial competitive advantage. Companies that operated in perfect and complex home market may have acquired a unique ability so that they have an absolute advantage compared to host country's companies [12]. FDI that aim sat gaining resources, markets, efficiency and strategic set high resource conditions for host countries [27], and host country's institutional environment also promote or restrict international behavior of multinational corporations. Home and host countries' similarity in institutional environment, factor endowments and other aspects, gives companies competitive advantages when they invest in similar host countries. And the countryspecific advantages can be divided into two parts: the similarity of institutions between home countries and host countries give companies endowment advantages, the similarity in production technology give companies comparative advantages. A country's economic strength is the cornerstone of formation of enterprises' competitiveness while state-owned resource endowments provide companies for resources of production, conversion and transaction required, and the institutional system established provide operating framework and the necessary safeguards for the enterprises [6] [7].

\subsection{Resource Endowment}

Unique resources, economic and institutional factors in the home country play a decisive role in the formation of country's corporate ownership [28]. The different conditions of home country creates different national trade advantages, scale advantages, location advantages, organization advantages and other specific advantages, and these country-specific advantages are the source of advantages for international competition, which has important significance for domestic enterprises to participate in overseas investment [29]. Thus, CSAs of multinationals in developing countries and developed country-specific are quite different [26]. Es- 
pecially in developing countries, rapid macroeconomic development, market size, potential, low relatively factor inputs cost, low operating costs, good growth, the accumulation of wealth and capital are much faster [30]. CSAs of home country is the cornerstone of a country's foreign investment enterprises [29] [30], which provides basic conditions for the development of domestic enterprises in the national income level, development level and other services. Characteristics of home country are important determinants of the ownership of enterprises to create competitive advantage and position in the international market. Empirical researches do show the greater influence of home country's competitiveness of enterprises compared with any other operating region [18] [32]-[36]. Specific factors of home country will lead to different strategic behaviors between companies from the same country and different countries [32] [36]-[40], some resources’ exclusive lead to other countries can't take the same competitive strategies, thus local enterprises could obtain protection and long-term development [28].

Seen from the above explanation, resource endowments of home country provide initial conditions for the enterprises, domestic enterprises can rely on the home country's unique natural resources to obtain original accumulation of wealth. Especially for the enterprises in developing country that has rich natural resources and a relatively backward scientific and technological level, home country's cheap labor market can save labor costs for enterprises; abundant natural resources can reduce raw material costs for the enterprise; immature market can also leave plenty of space for enterprises to grow.

Consistent with the specific advantages of the home country resource endowment, when multinational companies from developed countries conducting FDI, they will be more focused on the specific advantages of the host country. Compared to developing countries, developed countries in addition to home country's natural resources affected, will be influenced greater by host country's resource endowments. Host countries resource endowments mainly influence the investment motivation and location choice of multinational companies [11] [27] [41], and its influence towards location choices of host country varies according to different industries of the companies. Studies have shown that resource-seeking strategy and asset-seeking strategy have a higher requirement for country-specific advantages in the host country [27]; investment flows with the host resource endowments, market size positively correlated; the host country's economic development situation and cost efficiency have an important influence on motivation. And the level of technological development of the host country has a relatively high influence on technology acquisition motivation [41].

\subsection{Institutional Factors}

Institution contains regulative, normative and cultural-cognitive factors that provide stability and meaning to social life, as well as related activities and resources [42]. There is a big difference when enterprises operate in different market. Alocal business may gain a competitive advantage from its position in the network of relationships in the organization, such as familiarity with the local culture, customer and market characteristics [14]. National government policy and service support system can result in CSAs [9]. If government of home country encourages enterprises to actively explore overseas markets, it will provide some appropriate institutional and security [5], and home country’ relatively stable political environment will create favorable conditions for the internationalization of corporate. When the host country's economic and institutional environment is more developed, the number of value creation is greater, and form stronger multinational complementarity for existing capacities [43]. Home country institution affects the performance and its sustainability of enterprises by affecting competitive density (competitive intensity), in two ways: one by defining competitive rules because national institution context could promote or prohibit some types of transactions [44], for example, the establishment of anti-monopoly law is to prevent the conflict between enterprises, and increase the competitiveness of enterprises density [45]. Another way is that national institution context can affect the scale of exchange behavior that enterprises participate in. For example, perfect stock market makes it easier for companies to enter and obtain wealth. These institutions will also affect corporate behaviors, even though they operate in other countries, they can affect the business performance through direct extraterritoriality or influence it indirectly by adjusting business' operation activities.

Institutional environment in developing countries can make their local enterprises more easily gain legitimacy, since the growth and operation of local enterprises are in relatively familiar environment, and they have a good knowledge of institutions in the country. Relatively complete institutions in developed countries on the one hand will make the appropriate safeguards for the local business development and growth, on the 
other hand it will attract other countries' enterprise to invest. When multinational companies enter a country with relatedly complete national institution, the relatively clear legal provisions and regulations, it is possible to reduce the complexity of objective factors, which will reduce unnecessary trouble in the whole operate process. Developed and developing countries provide enterprises a different external environmental condition for FDI with varying degrees of complexity [46].

\section{The Evolution of CSAs to FSAs}

CSAs are the source of multinational corporations to maintain and create competitiveness [47]. A series of studies shows that corporate ownership advantages may be shaped by the home country [12]. For example, Dunning indicates that the ability of enterprises to obtain equity obviously relate to their specific countries' talent, in particular, the origin of home country [13]. According to Porter, the company's competitive advantage is the result of interaction between firm-specific factors (Diamond Model) and resources in home country [18]. Research about FSAs is changed by home countries’ environment has also been supported empirically [14] [37] [48]. Lall \& Siddhar than finds that non-US multinational FSAs is very different from the US companies [48]. In emerging market countries, for example, FSAs of emerging market countries mainly derives from comparative advantages of the home country, and it probably turn comparative advantage into competitive advantage successfully. Meanwhile, the CSAs of multinationals are enslaved to and formed from location-specific assets in their home country, the relationship between CSAs and their home countries are not only close interdependent but also dynamic interactive [28]. Resources in most emerging markets are exclusive, making it real that emerging market companies can create excess profits and enhance market competitiveness. More importantly, if the enterprise can internalize these resources and turn particular advantage into enterprise-specific assets, they can set up international competition advantages.

But there are some studies shows that CSAs are related to the characteristics of the host country [48]. In developed countries enterprise-specific features may depend not only on home country, but also the characteristics of the host country. Some researchers find that multinational companies' CSAs may be relate to host countries' competitors and the competitive environment [13] [49]. When considering different structure of resource endowment, demand conditions and competition, host countries will be important factors, because they may strengthen or weaken a company's strengths [32] [50]. Enterprises in developing countries' may face varied complexity external environment conditions of host countries [12] [46] when they try to internationalize, which have important influence on the development of enterprises. Itaki indicates that FSAs will be different in varied competitive conditions of host country [50]. Strategic literature also points out that enterprises should consider whether its' competitive position is sustainable or not [14]. The potential competitive advantage of a country in a specific value chain may provide enterprise for competitive advantage, such as $\mathrm{R} \& \mathrm{D}$ and manufacturing. When the activities of enterprises mainly conducts in home country and several overseas export market, the relationship between home country features and enterprise competitiveness will be strengthened. In this situation, countries with location advantages will become specific international competitiveness. When the country lose location advantage, companies will lose ownership advantages. However, when enterprises achieve most of its value-adding activities in the overseas market, the relationship between home country and FSAs will become weaker [51] [52].

It hasn't reached an agreement about the relationship between CSAs and FSAs. Chai indicates that when CSAs and FSAs realize complementary and synergy, the CSAs of host countries will contribute to multinational penetration in the market, and the host country will attract investment increasingly [53]. Rugman proposes FDI motivation theory vividly to describe the interaction of FSAs and CSAs in the motivation for FDI. While resource-seeking, market-seeking, efficiency-seeking and strategic assets seeking FDI all demand high level CSAs, the former three types demand high level FSAs and the last one doesn't [27].

Pei indicates that the advantages of enterprises to participate in international investment not only come from the strength of its self-accumulation and location advantages of host country, but also from the investment of home country [29]. Home country is the cornerstone of a country's foreign investment, which provides basic conditions for the level of national income and service development. Different home country development conditions create their own trade advantages, scale advantages, location advantages, organizational advantages and other specific advantages, which have significant implications for domestic enterprises to participate in FDI. Mean while the host country provides enterprise for location advantages, including specific natural resources, institutional conditions, economic politics and so on. FSAs are formed by both their own ownership advantages 
and internalization advantages as well as the specific advantages of home country and host countries.

Song argues that in terms of Chinese enterprises, whose FSAs are built up based on its' CSAs, It is an internal process that CSAs turn into FSAs [30]. Due to the supply rigid of the national resources structure and the stock in the short-term, Internalizing markets and resources of home country easily can't fully compensate for strategic resource gap in the global operations of Chinese enterprises and the rapid promotion of FSAs. Thus, the advantages of Chinese enterprises based on CSAs need use other complementarity CSAs (including the advantages of knowledge, technology resource endowments formation). The process of internal consists of two phases: first, internalize the CSAs into comparative ownership advantages. Second, the comparative advantages help enterprises to establish learning-oriented subsidiaries in developed economies, internalize the CSAs of host countries’ location and complementary advantages, then achieve the integration of global resources and pass the new built non-geographical advantages to parent company, and finally form FSAs within multinationals.

\section{Conclusion}

With economic globalization and increasing integration of international markets, the role of countries, no matter host countries or home countries, should not be overlooked when we regard enterprises as the main body to discuss international issues. Although existing literatures on country-specific advantages are not mature enough, its importance has become increasingly outstanding, especially the home country advantage. It should be the key point of future research that how to take advantage of country-specific advantages in the home country and internalize it as enterprise' internal advantage and thereby make enterprise in a dominant position in international competition. As China's economy has entered a new normal, economic growth mode is experiencing a new adjustment, country-specific advantages are facing structural changes, the traditional FSAs supported by factor conditions and supporting industries are faced with enormous challenges, since it is more and more difficult for companies to establish FSAs in the international market relying on CSAs. This article sorts out the relevant development and current situation about the concept of country-specific advantage for the readers and points out possible directions for future research, trying to make some contributions for future research around internationalization. The author believes future research about country-specific advantages can be broken through from the following directions: Do country-specific advantages affect cross-border mergers and acquisitions? If so, what is the mechanism? How do country-specific advantages affect the performance of multinationals? What is the respective influence of home and host countries towards multinationals operating in overseas markets? Due to limited space, the article does not describe these questions in detail, but the key to these questions is warmly welcomed in the future studies and the improvement and supplementation is also looked forward in international field.

\section{Acknowledgements}

The research was supported by the grants from Natural Science Foundation of Guangdong (2014a030313268) and the Fundamental Research Funds for the Central Universities, South China University of Technology (2015ZDXM02; 2015XMS25).

\section{References}

[1] Rugman, A.M. (1981) Inside the Multinationals: The Economics of Internal Markets. Columbia University Press, New York.

[2] Rugman, A.M. and Verbeke, V. (2001) Subsidiary-Specific Advantages in Multinational Enterprise. 22, 237-250.

[3] Zhang, H., Xu, J.F. and Jiang, Q.H. (2006) A Study on the Formation and Development of Subsidiary Special Advantage: A Perspective of Resources. Journal of International Trade, 4, 102-106

[4] Dunning, J.H. and Lundan, S.M. (2008) Institutions and the OLI Paradigm of the Multinational Enterprise. Asia Pacific Journal of Management, 25, 573-593. http://dx.doi.org/10.1007/s10490-007-9074-Z

[5] Song, Z.N. and Hu, J.B. (2012) FSAs, CSAs, and the Internationalization of Large-scale Firms: A Case of Southwest Ethnic Area. Guangxi Ethnic Studies, No. 3, 167-173.

[6] Havawini, G., Subramanian, V. and Verdin, P. (2004) The Home Country in the Age of Globalization: How Much Does It Matter for Firm Performance. Journal of World Business, No. 3, 99-112.

[7] Wan, W.P. (2005) Country Resource Environments, Firm Capabilities, and Corporate Diversification Strategies. Journal of Management Studies, 42, 161-182. http://dx.doi.org/10.1111/j.1467-6486.2005.00492.x 
[8] Pei, C.H., Zhao, X.Z. and Peng, L. (2007) Economic Globalization and Contemporary International Trade. Social Sciences Academic Press, London.

[9] Zhang, J.F. (2014) Discussion on China’s Foreign Direct Investment Dynamic Mechanism. Modern Economic Research, No. 11, 58-62.

[10] Filatotchev, I., Strange, R., Piesse, J. and Lien, Y.-C. (2007) FDI by Firms from Newly Industrialised Economies in Emerging Markets: Corporate Governance, Entry Mode and Location. Journal of International Business Studies, 38, 556-572. http://dx.doi.org/10.1057/palgrave.jibs.8400279

[11] Xiao, W. and Zhou, J.Z. (2014) Chinese OFDI Location Preferences with Country-Specific Advantages: An Empirical Analysis Based on Firms' Investment Motivation and Capability. Journal of Zhejiang University (Humanities and Social Sciences), 44, 184-196.

[12] Erramilli, K.M., Agarwal, S. and Kim, S.-S. (1997) Are Firm-Specific Advantage Location-Specific Too? Journal of International Business Studies, 28, 735-757. http://dx.doi.org/10.1057/palgrave.jibs.8490117

[13] Dunning, J.H. (1981) Explaining the International Direct Investment Position of Countries: Towards a Dynamic or Development Approach. Weltwirtschaftliches Archiv, 177, 30-64. http://dx.doi.org/10.1007/BF02696577

[14] Shan, W.J. and Hamilton, W. (1991) Country-Specific Advantage and International Cooperation. Strategic Management Journal, 12, 419-432. http://dx.doi.org/10.1002/smj.4250120603

[15] Hymer, S. (1960) The International Operations of National Firms: A Study of Direct Foreign Investment. The MIT Press, Cambridge.

[16] Wells Jr., L.T. (1983) Third World Multinationals: The Rise of Foreign Investment of U.S. Advertising Agencies. The MIT Press, Cambridge.

[17] Porter, M.E. (1980) Competitive Strategy. Free Press, New York.

[18] Porter, M.E. (1990) The Competitive Advantage on Nations. Free Press, New York.

[19] Chen, W.P. (2002) Competitive Advantage Theory: Inspiration for China's Development of Int'l Service Trade. International Economics and Trade Research, 2, 2-4.

[20] Rugman, A.M. and D’Cruz, J.R. (1993) The Double Diamond Model of International Competitiveness: The Canadian Experience. Management International Review, 33, 17-39.

[21] Kim, M.Y. (2006) Inequality in Globalization: An Extension of the Gini Index from the Perspective of National Competitiveness. Journal of International Business and Economy, 7, 119-140.

[22] Moon, H.C., Rugman, A.M. and Verbeke, A. (1995) The Generalized Double Diamond Approach to International Competitiveness. Research in Global Strategic Management: Beyond the Diamond, 6, 97-114.

[23] Moon, H.C., Rugman, A.M. and Verbeke, A. (1998) A Generalized Double Diamond Approach to the Global Competitiveness of Korea and Singapore. International Business Review, 7, 135-150. http://dx.doi.org/10.1016/S0969-5931(98)00002-X

[24] Cho, D.S. (1994) A Dynamic Approach to International Competitiveness: The Case of Korea. Journal of Far Eastern Business, 1, 17-36. http://dx.doi.org/10.1080/13602389400000002

[25] Cho, D.S. and Moon, H.C. (2000) From Adam Smith to Michael Porter. World Scientific, Singapore.

[26] Dunning, J.H. (2000) The Eclectic Paradigm as an Envelope for Economic and Business Theories of MNE Activity. International Business Review, 9, 163-190. http://dx.doi.org/10.1016/S0969-5931(99)00035-9

[27] Rugman, A. (2010) Reconciling Internalization Theory and the Eclectic Paradigm. Multinational Business Review, 18, 1-12. http://dx.doi.org/10.1108/1525383X201000007

[28] Chai, Z.D. and Liu, H.J. (2014) An Analysis of the Home Factors in Competitive Advantages of the Emerging Market's MNEs. Nanjing Journal of Social Sciences, 8, 24-31.

[29] Pei, C. and Zheng, W. (2011) Country-Specific Advantages: Supplementary Explanation of International Investment Theory. Economic Research Journal, No. 11, 21-35.

[30] Song, Z.N. and Yin, Z.M. (2013) The Transfer from Country-Specific Advantages to Firm-Specific Advantages: Logic Paths and Realistic Barriers. International Economics and Trade Research, No. 6, 25-35.

[31] Chen, R.J. (2011) World Economics Pattern Change and China Export-Orient Economy Reforming. International Business Research, No. 4, 3-8.

[32] Dunning, J.H. (1995) Reappraising the Eclectic Paradigm in an Age of Alliance Capitalism. Journal of International Business Studies, 26, 461-491. http://dx.doi.org/10.1057/palgrave.jibs.8490183

[33] Pauly, L.W. and Reich, S. (1997) National Structures and Multinational Corporate Behaviour: Enduring Differences in the Age of Globalization. International Organization, 51, 1-30. http://dx.doi.org/10.1162/002081897550285 
[34] Nachum, L. and Rolle, J.D. (1999) Home Country and Firm-Specific Ownership Advantages: A Study of US, UK and French Advertising Agencies. International Business Review, 8, 633-660. http://dx.doi.org/10.1016/S0969-5931(99)00023-2

[35] Nachum, L. and Rolle, J.D. (1999) The National Origin of the Ownership Advantages of Firms: A Case Study of the Advertising Industry. The Service Industries Journal, 19, 17-48.

[36] Nachum, L. (1999) The Origins of the International Competitiveness of Firms: The Impact of Location and Ownership in Professional Service Industries. Edward Elgar, Aldershot and Brookfield.

[37] Schroath, F.W., Hu, M.Y. and Chen, H. (1993) Country-of-Origin Effects of Foreign Investments in the People's Republic of China. Journal of International Business Studies, 24, 277-290. http://dx.doi.org/10.1057/palgrave.jibs.8490233

[38] Shane, S. (1994) The Effect of National Culture on the Choice between Licensing and Direct Foreign Investment. Strategic Management Journal, 15, 627-642. http://dx.doi.org/10.1002/smj.4250150805

[39] Yip, S.G., Johansson, K.J. and Roos, J. (1997) Effects of Nationality on Global Strategy. Management International Review, 37, 365-385.

[40] Zaheer, S. and Zaheer, A. (1997) Country Effects on Information Seeking in Global Electronic Networks. Journal of International Business Studies, 28, 77-100. http://dx.doi.org/10.1057/palgrave.jibs.8490094

[41] Cong, J. and Zhang, H. (2014) Study on the Motivation of China’s Outward Foreign Direct Investment-Based on the Characteristics of Host Countries. Journal of Yunnan University of Finance and Economics, No. 4, 104-113.

[42] Scott, W.R. (2006) Institutions and Organizations: Ideas, Interests, and Identities. SAGE Publications, Thousand Oaks.

[43] Gubbi, S.R., Aulakh, P.S., Ray, S., Sarkar, M.B. and Chittoor, R. (2010) Do International Acquisitions by Emerging-Economy Firms Create Shareholder Value? The Case of Indian Firms. Journal of International Business Studies, 41, 397-418. http://dx.doi.org/10.1057/jibs.2009.47

[44] Tolbert, P.S. and Zucker, L.G. (1983) Institutional Sources of Change in the Formal Structure of Organizations: The Diffusion of Civil Service Reform, 1880-1935. Administrative Science Quarterly, 28, 22-39. http://dx.doi.org/10.2307/2392383

[45] Scherer, F.M. and Ross, D. (1990) Industrial Market Structure and Performance.

[46] Beamish, P.W. (1985) The Characteristics of Joint Ventures in Developed and Developing Countries. Columbia Journal of World Business, 20, 13-19.

[47] Cho, D.S., Moon, H.C. and Kim, M.Y. (2009) Does One Size Fit All? A Dual Double Diamond Approach to Country-Specific Advantages. Asian Business \& Management, 8, 83-102. http://dx.doi.org/10.1057/abm.2008.27

[48] Lall, S. and Siddharthan, N.S. (1982) The Monopolistic Advantages of Multinationals: Lessons from Foreign Investment in the U.S. Economic Journal, 92, 668-683. http://dx.doi.org/10.2307/2232556

[49] Buckley, P.J. (1990) Problems and Developments in the Core Theory of International Business. Journal of International Business Studies, 21, 657-665. http://dx.doi.org/10.1057/palgrave.jibs.8490346

[50] Itaki, M. (1991) A Critical Assessment of the Eclectic Theory of the Multinational Enterprise. Journal of International Business Studies, 22, 445-460. http://dx.doi.org/10.1057/palgrave.jibs.8490310

[51] Cantwell, J. (1989) British Multinationals: Origins, Management and Performance. Economic History Review, 42, 144-145. http://dx.doi.org/10.2307/2597067

[52] Cantwell, J. (1992) The Methodological Problems Raised by the Collection of Foreign Direct Investment Data. Scandinavian International Business Review, 1, 86-102. http://dx.doi.org/10.1016/0962-9262(92)90038-8

[53] Chai, Z.D. (2007) Competitive Advantages of the Emerging Market's MNEs: Firm-Specific or Home Factors? AsiaPacific Economic Review, No. 3, 25-28. 